\title{
Supplementation for beef cattle on Marandu grass pastures with different herbage allowances
}

\author{
A. P. De Oliveira ${ }^{\mathrm{A}}$, D. R. Casagrande ${ }^{\mathrm{B}}$, L.M. M. Aertipaglia $^{\mathrm{C}}$, R. P. Barbero ${ }^{\mathrm{A}}$, , T. T. Berchielli $^{\mathrm{A}}$, \\ A. C. Ruggieri ${ }^{\mathrm{A}}$ and R. A. Reis ${ }^{\mathrm{A}, \mathrm{D}}$ \\ AFaculdade de Ciências Agrárias e Veterinárias, UNESP - Univ Estadual Paulista, Jaboticabal, SP, Brazil. \\ ${ }^{\mathrm{B}}$ Universidade Federal de Lavras, UFLA, Lavras, MG, Brazil. \\ CUniversidade Camilo Castelo Branco, UNICASTELO, Descalvado, SP, Brazil. \\ ${ }^{\mathrm{D} C}$ Corresponding author. Email: rareis@fcav.unesp.br
}

\begin{abstract}
The objective of this study was to evaluate the performance of beef heifers on Stapf. cv. Marandu grass pastures that were managed at three herbage allowances under continuous grazing with a variable stocking rate and were provided with mineral mix supplement or supplements with energy and protein. Seventy-two test heifers and 48 put-and-take heifers were used in a randomised design in a $3 \times 2$ factorial arrangement [three herbage allowances $(1.5,2.0$, and $2.5 \mathrm{~kg}$ of green dry matter $/ \mathrm{kg}$ of bodyweight, and two supplementation levels (mineral mix or $0.3 \%$ bodyweight of a mineral-protein-energy supplement)], with two replicates per treatment (paddocks), to maintain the preestablished forage allowance. No significant difference was observed in the gain per hectare as a function of the herbage allowance, but $2.5 \mathrm{~kg}$ green dry matter/ $\mathrm{kg}$ bodyweight provided the greatest average daily gain of bodyweight $(0.605 \mathrm{~kg} /$ animal/day). The energy/protein supplementation provided the greatest average daily gain compared with animals fed only the mineral mix. The supplements in the diet of beef heifers fed at $0.3 \%$ of bodyweight increased bodyweight gains without compromising the gain per hectare at different herbage allowances.
\end{abstract}

Additional keywords: continuous grazing, heifers, performance, productivity.

Received 13 June 2014, accepted 2 October 2014, published online 19 February 2015

\section{Introduction}

Brachiaria brantha (Hochst.) Stapf. cv. Marandu (Marandu grass) is the most widely cultivated forage plant in Brazil and plays a key role in pasture-based systems. However, due to its production potential, the productivity, efficiency and sustainability of its use in production systems falls short of its optimal potential, especially due to inappropriate pasture management.

Herbage intake is the main factor affecting animal performance, and it is closely related to the herbage allowance and sward structure (Da Silva et al. 2013). An increase in herbage allowance can promote increased individual performance, but when the stocking rate is reduced, the production per area decreases (Reis et al. 2013).

Recent studies with tropical grasses have confirmed that the management strategy based on monitoring the availability and controlling the sward height generates highly consistent relationships between the responses of the forage plant and animals, which increases the understanding of the effects of sward-structure variations on the production and persistency of plants (Barbosa et al. 2007) and on animal performance (Casagrande et al. 2011).

Distinct grazing heights or herbage allowances, developmental stages and herbage-production seasonality modify the structure and, consequently, the quality of a pasture. Studies evaluating the intake and performance of grazing animals with different herbage allowances require descriptions of the availabilities and structural conditions of pastures for the interpretation and comparison of results (Gontijo Neto et al. 2006).

According to Moore et al. (1999), the use of supplements can result in changes of forage dry matter (DM) intake. Casagrande et al. (2011) suggests there has been a great interest in adjusting the pasture production system through supplementation, and supplementation has been used in the dry/rainy season transition as an option to provide limiting nutrients and to increase the efficiency of pasture utilisation, which ultimately increases productivity.

The hypothesis of this study was that providing an energy/ protein supplement for beef heifers during the rainy season and rainy/dry season transition can improve their performance compared with animals fed only a mineral mix without compromising the productivity per hectare on Marandu pastures using different herbage allowances under continuous grazing.

\section{Materials and methods}

\section{Geographic location and experimental period}

The study was conducted during the rainy season, from January to May, with January as a period of adaptation and February, 
March and April as Periods 1, 2 and 3, respectively. These pastures belonged to the Department of Animal Science of the Faculty of Agricultural and Veterinary Sciences at São Paulo State University, located in Jaboticabal/SP, Brazil, $\left(21^{\circ} 15^{\prime} 22^{\prime \prime} \mathrm{S}\right.$ latitude, $48^{\circ} 18^{\prime} 58^{\prime \prime} \mathrm{W}$ longitude and 595-m elevation). The Brachiaria brizantha (Hochst ex A. Rich) Stapf cv. Marandu pastures were established in 2001 in a Hapludox soil type. The climate in Jaboticabal City is a subtropical Awa type, with rainy summers and dry winters (Table 1).

The following chemical characteristics of the soil (upper layer, 0-20 cm) were: $\mathrm{pH}, 5.1$; organic matter, $22.5 \mathrm{~g} / \mathrm{DM}^{3}$; phosphorus in resin, $8.8 \mathrm{~g} / \mathrm{DM}^{3}$; potassium, $2.3 \mathrm{mmol}_{\mathrm{c}} / \mathrm{DM}^{3}$; calcium, $13.6 \mathrm{mmol}_{\mathrm{c}} / \mathrm{DM}^{3}$; magnesium, $9.7 \mathrm{mmol}_{\mathrm{c}} / \mathrm{DM}^{3} ; \mathrm{H}^{+} \mathrm{Al}$, $25.2 \mathrm{mmol}_{\mathrm{c}} / \mathrm{DM}^{3}$; sum of bases, $26.1 \mathrm{mmol}_{\mathrm{c}} / \mathrm{DM}^{3} ; \mathrm{CEC}$, $50.9 \mathrm{mmol}_{\mathrm{c}} / \mathrm{DM}^{3}$, at $\mathrm{pH} 7(\mathrm{~T})$; and base saturation of $51.5 \%$. Based on this soil analysis, maintenance fertilisation for Marandu grass was performed in January by applying 200 and $160 \mathrm{~kg} \mathrm{ha}^{-1}$ year ${ }^{-1}$ of $\mathrm{N}$ and $\mathrm{K}_{2} \mathrm{O}$ in the forms of urea and potassium chloride.

The experimental area consisted of a 12-ha pasture, which was divided into 12 paddocks of $1.3,1.0$ and 0.7 ha; the treatments with the lowest herbage allowance were installed in the smallest paddocks, and vice versa. The size of each paddock was modified so that the number of animals tested in them was similar to avoid interference with grazing behaviour. In addition, a reserve area of 8 ha was allocated to the animals used to control the forage allowance.

\section{Animals and grazing method}

Six test animals were used in each paddock, totalling 72 experimental heifers. In addition to these, 48 heifers were used to control the stocking rate (put-and-take) and to maintain the pre-established herbage allowance in the treatments. Crossbred heifers (Santa Gertrudis $\times$ Nellore cows and Braunvieh bulls) were $\sim 7$ months old with an initial bodyweight (BW) of $200 \mathrm{~kg}$ that were from the same farm. At the beginning of the experiment, the animals were weighed and randomly distributed across the treatments and endo- and ecto-parasites were controlled at that time. Animal performance was determined by weighing them at time zero (after an adaptation period of 18 days) and subsequently every 28 days thereafter, always after a previous solid- and liquid-deprivation period of $15 \mathrm{~h}$.
The grazing method utilised was continuous grazing with a variable stocking rate, using beef heifers in the growth phase. The number of heifers was adjusted every fortnight according to the BW of the animals in each paddock in relation to the herbage mass. This was done to maintain the herbage allowance, according to the method of Sollenberger and Cherney (1995) with the following formula: herbage allowance $[\mathrm{kg}$ green dry matter $(\mathrm{GDM}) / \mathrm{kg} \mathrm{BW]}=$ green mass $(\mathrm{kg} / \mathrm{ha}) / \mathrm{BW}(\mathrm{kg} / \mathrm{ha})$. Of the heifers present in each paddock, six were considered test animals that had an average daily gain that was estimated. The BW gain per hectare was estimated as the product of the average daily gain of the tested heifers by the stocking rate of the paddock, expressed as days-heifer/ha.

\section{Experimental treatments}

The treatments were arranged in a $3 \times 2$ factorial design, i.e. three herbage allowances $\left(1.5,2.0\right.$ and $2.5 \mathrm{~kg} \mathrm{GDM} \mathrm{kg}^{-1}$ of BW) (Sollenberger and Cherney 1995) with two types of supplementation (mineral-protein-energy supplement or mineral salt), with two replicates, totalling 12 paddocks. The protein-energy supplement contained $25 \%$ crude protein $(\mathrm{CP})$ and $67 \%$ total digestible nutrients (TDN) and was composed of citrus pulp (51.2\%), cottonseed meal with $38 \%$ CP (38.96\%), urea $(2.69 \%)$ and minerals $(7.27 \%)$, and the other was a mineral mix, both of which were provided by a commercial enterprise (Table 2). Supplements were supplied daily at 1400 hours in a fashion that did not interfere with the grazing behaviour of the animals; the protein-energy supplement was offered at an amount of $0.3 \% \mathrm{BW} \mathrm{day}^{-1}$, and the mineral mix was available ad libitum ( $\left.\sim 0 \mathrm{~g} \mathrm{animal}^{-1} \mathrm{day}^{-1}\right)$.

\section{Herbage quantitative analyses}

Total herbage mass was evaluated throughout the experimental period using a double-sampling technique (Sollenberger and Cherney 1995), in which destructive sward-height readings were taken using the rising-plate technique. Total herbage mass was estimated by a regression equation with the plant height compressed, as evaluated from a cut made at the soil level. The cut area corresponded to the dimensions of the rising plate, i.e. $0.246 \mathrm{~m}^{2}$ of area, using iron rings.

Fifty readings were randomly taken using the heightcompressed sward samples, in addition to another five

Table 1. Meteorological data during the rainy and rainy/dry season transition corresponding to the period that affects the experimental data in Jaboticabal, São Paulo, Brazil

MaxT, maximum temperature; MinT, minimum temperature; MeanT, mean temperature; RH, relative air humidity; ND, number of days with rain. Source: Agrometeorological Station of the Department of Exact Sciences of FCAV/UNESP

\begin{tabular}{lcccccrc}
\hline Month & MaxT $^{\circ} \mathrm{C}$ & MinT $^{\circ} \mathrm{C}$ & MeanT $^{\circ} \mathrm{C}$ & $\begin{array}{c}\mathrm{RH} \% \\
\text { Precipitation } \\
\mathrm{mm}\end{array}$ & $\mathrm{ND}$ & $\begin{array}{c}\text { Insolation } \\
\text { hours }\end{array}$ \\
\hline November & 31.4 & 18.8 & 24.3 & 67.6 & 41.7 & 7 & 220.2 \\
December & 29.5 & 19.2 & 23.5 & 77.7 & 242.6 & 19 & 204.3 \\
January & 31.3 & 20.3 & 25.0 & 74.7 & 237.0 & 18 & 236.0 \\
February & 30.7 & 20.3 & 24.2 & 82.9 & 416.4 & 15 & 181.1 \\
March & 31.0 & 20.4 & 24.5 & 81.4 & 136.9 & 16 & 221.0 \\
April & 29.5 & 17.2 & 22.4 & 74.8 & 10.4 & 4 & 255.2 \\
May & 26.6 & 12.8 & 18.7 & 70.1 & 4.0 & 3 & 249.4 \\
\hline
\end{tabular}


Table 2. Chemical composition of the mineral and mineralprotein-energy supplements utilised in the experimental period

Data are expressed as the percentage of dry matter. NDF (neutral detergent fibre); $\mathrm{ADF}$ (acid detergent fibre); IVOMD (in vitro organic matter digestibility)

\begin{tabular}{lcc}
\hline Component & $\begin{array}{c}\text { Mineral-protein-energy } \\
\text { supplement }\end{array}$ & Mineral mix \\
\hline Crude protein (\%) & Analysed & \\
NDF (\%) & 25.3 & - \\
ADF (\%) & 17.3 & - \\
Lignin (\%) & 15.8 & - \\
IVOMD (\%) & 4.2 & - \\
& 76.0 & \\
Sodium $(\mathrm{g} / \mathrm{kg})$ & & 13 \\
Calcium $(\%)$ & 13 & 15.85 \\
Phosphorus $(\%)$ & 2.3 & 7.81 \\
Sulfur $(\mathrm{g} / \mathrm{kg})$ & 0.6 & 40 \\
Zinc $(\mathrm{mg} / \mathrm{kg})$ & 3 & 5000 \\
Copper $(\mathrm{mg} / \mathrm{kg})$ & 148 & 1350 \\
Manganese $(\mathrm{mg} / \mathrm{kg})$ & 40 & 1040 \\
Iodine $(\mathrm{mg} / \mathrm{kg})$ & 30 & 100 \\
Cobalt $(\mathrm{mg} / \mathrm{kg})$ & 3 & 80 \\
Selenium $(\mathrm{mg} / \mathrm{kg})$ & 2.4 & 26 \\
Monensin $(\mathrm{mg} / \mathrm{kg})$ & 0.8 & 0 \\
\hline
\end{tabular}

readings at points with greater and lower sward heights, the herbage of which was collected at the soil level according to the border limits of the disk. The average total herbage mass was estimated from the adjusted linear regression between height and dry weight of the 10 herbage samples harvested and from the average of the readings randomly taken in each paddock. In the first and last destructive sampling, samples were collected to estimate the available quantities of leaf and stem.

\section{Herbage qualitative analyses}

Forage chemical composition was estimated in monthly samplings with extrusa samples. One esophageal-cannulated Nellore animal (500 kg of BW) was fitted with a screenbottom fabric collection bags that were used to drain the excess saliva. On the day before collection, the animal was deprived of solid food for $\sim 12 \mathrm{~h}$. On the collection days, the oesophageal cannula was removed and the collection bag was placed. The animal was monitored for $20 \mathrm{~min}$, without interference to its grazing behaviour. At the end of the sampling period, the bag was removed and the extrusa sample was homogenised and dried in an oven at $55^{\circ} \mathrm{C}$ for $72 \mathrm{~h}$ and was then processed in a Wiley mill with a $1-\mathrm{mm}$ mesh sieve.

The CP content was determined using the Kjeldahl method (Association of Official Analytical Chemists - AOAC 1990). The neutral detergent fibre (NDF) and acid detergent fibre (ADF) content were determined using the analytical techniques described by Mertens (2002), except for the use of polyester filter bags $(25-\mu$ porosity). The lignin was determined by the solubilisation of cellulose with sulfuric acid according to the methods of Van Soest and Robertson (1985). The fractionation of $\mathrm{N}$ compounds (fraction A) was determined following the methodology of Licitra et al. (1996), and the $\mathrm{N}$ fractions
N-NDF $\left(\mathrm{B}_{3}\right)$ and N-ADF $(\mathrm{C})$ were determined by the system proposed by the Cornell Net Carbohydrate and Protein System, according to Sniffen et al. (1992).

A gas production analysis, to determine the in vitro DM digestibility, and the TDN were performed according to the methodology used by Theodorou et al. (1994) and modified by Mauricio et al. (1999).

The incubation period was $72 \mathrm{~h}$, in which pressure readings were taken at 2, 4, 6, 8, 10, 12, 24, 26, 28, 30, 32, 36, 48, 52, 56, 60 and $72 \mathrm{~h}$ of incubation. The results were corrected for the blank (a bottle containing a buffered rumen solution, without a sample) and for the standard (Tifton 85 grass hay) at $24 \mathrm{~h}$ of incubation, and together with the levels of the chemical components of the feed (ash, protein and ether extract), they were used to predict the energy value and the in vitro organic matter digestibility of the incubated samples.

The data pertaining to pressure readings (psi) were converted to volume $(\mathrm{mL})$ by the equation described below, which was obtained with pressure readings from different known amounts of gas volumes in the bottles and was maintained at the same temperature conditions as in the incubation (Mota et al. 2005):

$$
Y=5.5452 \times-0.1569,
$$

where $Y$ is the gas volume $(\mathrm{mL})$ and $\times$ is the pressure (psi).

The in vitro organic matter digestibility (IVOMD) and metabolisable energy (ME) were calculated using the equations recommended by Menke and Steingass (1988):

$$
\begin{array}{rl}
\operatorname{ME}(\mathrm{MJ} / \mathrm{kg} \mathrm{DM})=2 & 2.20+(0.136 * \mathrm{gas} 24)+(0.0057 * \mathrm{CP}) \\
+ & (0.00029 * \mathrm{EE}) \text { and } \\
\operatorname{IVOMD~}(\mathrm{g} / \mathrm{kg} \mathrm{DM})= & 14.88+(0.889 * \operatorname{gas} 24)+(0.045 * \mathrm{CP}) \\
+ & (0.065 * \mathrm{MM}),
\end{array}
$$

where gas2 4 is the gas production in vitro during $24 \mathrm{~h}$ of incubation (mL/0.2 g DM); the CP, ether extract (EE) and mineral matter (MM) values are expressed as $\mathrm{g} / \mathrm{kg} \mathrm{DM}$.

Subsequently, all these values were converted to TDN using the following equations recommended by the National Research Council (NRC) (2001);

$$
\begin{gathered}
\operatorname{DE}(\mathrm{Mcal} / \mathrm{kg} \mathrm{DM})=\mathrm{ME} / 0.82 \\
\operatorname{TDN}(\%)=\mathrm{DE} / 4.409 * 100 .
\end{gathered}
$$

\section{Experimental design and statistical analyses}

The experimental design was randomised blocks with two replicates in a $3 \times 2$ factorial arrangement with three herbage allowances (1.5, 2.0 and $2.5 \mathrm{~kg} \mathrm{GDM} / \mathrm{kg}$ of $\mathrm{BW})$ and two supplementation types (mineral mix and mineral-proteinenergy supplement). The statistical analysis was performed in a randomised block design with measures repeated over time (months), using the PROC MIXED procedure of the SAS (SAS Institute 2002) statistical package. The best covariance structure was chosen using the minimum Schwarz's Bayesian Criterion value as a criterion. Regression analysis was used to compare the herbage allowance, and the means were compared $(P<0.10)$ for the effects of the period, supplementation and interactions between the factors under study. 


\section{Results}

During the adaptation period and Period 1, the herbage allowances observed were close to the pre-established values; however, as the experiment progressed, it was not possible to maintain the desired herbage allowances of $1.5,2.0$ and $2.5 \mathrm{~kg}$ $\mathrm{GDM} / \mathrm{kg} \mathrm{BW}$, especially during the final experimental period (Table 3). The analysis and interpretation was based on the forage allowance pre-established, because although there have been changes during the experimental periods, we cannot rule that such changes are the result of pre-established treatments. The stocking rates varied according to the interaction between herbage allowance and the studied months $(P<0.10)$. The greatest stocking rates were obtained at the lowest herbage allowance, which were reduced in accordance with the increase in forage availability. There was no difference between the herbage allowances of 2.0 and $2.5 \mathrm{~kg} \mathrm{GDM} / \mathrm{kg}$ $\mathrm{BW}$ in the third period.

The sward height was affected by the interaction between the evaluated months and the herbage allowance $(P<0.10)$. In February, the greatest height was obtained in the pastures managed with the lowest herbage allowance (Table 4). In the following month, there was an inversion, with the lowest height observed in the pastures managed under the lowest herbage allowance. Comparing the first 2 months evaluated, it was observed that the sward height decreased by $13.5 \mathrm{~cm}$ in pastures with lower forage availability, whereas in those managed with 2.0 and $2.5 \mathrm{~kg} \mathrm{GDM} / \mathrm{kg} \mathrm{BW}$, the sward height decreased by 5.1 and $5.3 \mathrm{~cm}$, respectively. No difference between the herbage allowances was found in April, and the lowest height was also observed during this month, which is a direct reflection of the observed climatic conditions (Table 1).

Herbage chemical composition data are described in Tables 5 and 6 . No differences were found for the chemical composition of the herbage; however, during the experimental period, the lowest $\mathrm{CP}$ value was 8.38 , which was observed in April. This was due to the greater proportion of dead material observed in the forage harvested in that period.

Table 7 shows the average animal gains per area and per animal according to the herbage allowances and supplementations. No significant difference was observed for the gain per area according to the herbage allowance. However, it should be noted that the gain per area at the lowest forage

Table 3. Observed herbage allowance (HA) and stocking rate of the Marandu-grass pasture by month and different herbage allowances Means followed by the same lowercase letter in the row and uppercase letter in the column (stocking rate) do not differ by a $t$-test $(P<0.10)$

\begin{tabular}{lccc}
\hline Month & \multicolumn{3}{c}{ Intended HA } \\
& 1.5 & 2.0 & 2.5 \\
\hline \multirow{3}{*}{ January } & 1.68 & Observed HA $(\mathrm{kg} \mathrm{FDM} / \mathrm{kg} \mathrm{BW})$ \\
February & 1.45 & 1.82 & 2.47 \\
March & 1.29 & 1.82 & 2.01 \\
& & Stocking rate (AU/ha) & \\
January & $6.43 \mathrm{Aa}$ & $5.17 \mathrm{Ab}$ & $4.06 \mathrm{Ac}$ \\
February & $5.81 \mathrm{Ba}$ & $5.27 \mathrm{Ab}$ & $4.38 \mathrm{Ac}$ \\
March & $5.16 \mathrm{Ca}$ & $4.39 \mathrm{Bb}$ & $4.49 \mathrm{Ab}$ \\
\hline
\end{tabular}

availability (1.5 kg GDM/kg BW) in February was greater in the two levels of supplementation in relation to the other forage allowance treatments. This occurred during the period of greatest leaf mass and green material.

Supplementation in the rainy season at moderate levels $(0.3 \%$ of $\mathrm{BW})$ enabled greater weight gains compared with

Table 4. Herbage mass and sward structure of Marandu grass pasture in different periods and with different herbage allowances (HA)

Means followed by the same lowercase letter in the row and uppercase letter in the column do not differ by a $t$-test $(P<0.10)$

\begin{tabular}{lccc}
\hline Month & \multicolumn{3}{c}{ Intended HA } \\
& 1.5 & 2.0 & 2.5 \\
\hline January & $4868 \mathrm{Aa}$ & Fresh & herbage mass $(\mathrm{kg} / \mathrm{ha})$ \\
February & $3791 \mathrm{Ba}$ & $4223 \mathrm{Ab}$ & $4526 \mathrm{Aab}$ \\
March & $3005 \mathrm{Cb}$ & $4167 \mathrm{Aa}$ & $3975 \mathrm{Ba}$ \\
& & $3595 \mathrm{Ba}$ & $3283 \mathrm{Cab}$ \\
January & $27.4 \mathrm{Aa}$ & Height $(\mathrm{cm})$ & \\
February & $13.9 \mathrm{Bb}$ & $23.6 \mathrm{Ab}$ & $23.3 \mathrm{Ab}$ \\
March & $13.3 \mathrm{Ba}$ & $18.5 \mathrm{Ba}$ & $18.0 \mathrm{Ba}$ \\
& & $16.5 \mathrm{Ba}$ & $15.8 \mathrm{Ba}$ \\
January & $2332 \mathrm{Aab}$ & Leaf $(\mathrm{kg} / \mathrm{ha})$ & $2434 \mathrm{Aa}$ \\
February & $1135 \mathrm{Bb}$ & $2140 \mathrm{Ab}$ & $1336 \mathrm{Bab}$ \\
& & $1409 \mathrm{Ba}$ & \\
January & $2536 \mathrm{Aa}$ & Stem $(\mathrm{kg} / \mathrm{ha})$ & $2092 \mathrm{Ab}$ \\
February & $1870 \mathrm{Bb}$ & $2084 \mathrm{Ab}$ & $1862 \mathrm{Ab}$ \\
\hline
\end{tabular}

Table 5. Mean data for crude protein (CP) and fractionation of the protein from extrusa of cattle on Brachiaria brizantha cv. Marandu pastures under continuous grazing with different herbage allowances (HA) and supplementation

$\mathrm{CP}$ is expressed as the percentage of dry matter

\begin{tabular}{|c|c|c|c|c|c|c|}
\hline \multirow[t]{2}{*}{ Month } & \multirow[t]{2}{*}{ HA } & \multirow[t]{2}{*}{$\mathrm{CP}$} & \multicolumn{4}{|c|}{$\mathrm{CP}$ fractions $(\% \mathrm{CP})$} \\
\hline & & & A & $\mathrm{B} 1+\mathrm{B} 2$ & B3 & $\mathrm{C}$ \\
\hline \multicolumn{7}{|c|}{ Mineral } \\
\hline \multirow[t]{3}{*}{ January } & 1.5 & 12.09 & 30.14 & 17.99 & 35.63 & 16.24 \\
\hline & 2.0 & 12.27 & 32.18 & 28.33 & 22.94 & 16.55 \\
\hline & 2.5 & 11.59 & 28.93 & 31.62 & 26.23 & 13.22 \\
\hline \multirow[t]{3}{*}{ February } & 1.5 & 8.59 & 27.17 & 18.13 & 35.16 & 19.54 \\
\hline & 2.0 & 8.54 & 35.71 & 21.64 & 21.51 & 21.14 \\
\hline & 2.5 & 8.78 & 35.67 & 18.98 & 27.69 & 17.66 \\
\hline \multirow[t]{3}{*}{ March } & 1.5 & 9.25 & 34.91 & 28.60 & 22.18 & 14.31 \\
\hline & 2.0 & 8.38 & 26.72 & 29.97 & 27.68 & 15.63 \\
\hline & 2.5 & 9.43 & 34.38 & 27.70 & 25.23 & 12.69 \\
\hline \multicolumn{7}{|c|}{ Mineral-protein-energy supplement } \\
\hline \multirow[t]{3}{*}{ January } & 1.5 & 10.81 & 33.04 & 24.66 & 28.15 & 14.15 \\
\hline & 2.0 & 11.34 & 27.45 & 24.41 & 31.34 & 16.80 \\
\hline & 2.5 & 10.11 & 23.25 & 30.02 & 27.51 & 19.22 \\
\hline \multirow[t]{3}{*}{ February } & 1.5 & 9.26 & 29.80 & 15.61 & 33.96 & 20.63 \\
\hline & 2.0 & 9.87 & 27.83 & 25.51 & 31.70 & 14.96 \\
\hline & 2.5 & 8.60 & 27.21 & 25.64 & 29.15 & 18.00 \\
\hline \multirow[t]{3}{*}{ March } & 1.5 & 8.67 & 37.61 & 25.29 & 17.55 & 19.54 \\
\hline & 2.0 & 9.19 & 28.51 & 26.59 & 31.92 & 12.98 \\
\hline & 2.5 & 10.08 & 25.54 & 33.34 & 28.37 & 12.75 \\
\hline
\end{tabular}


Table 6. Mean values of neutral detergent fibre (NDF), acid detergent fibre (ADF), lignin (LIG), hemicellulose (HEM), cellulose (CEL), in vitro organic matter digestibility (IVOMD) and total digestible nutrients (TDN) of the extrusa of cattle on Brachiaria brizantha cv. Marandu pastures with continuous stocking rate and different herbage allowances (HA) and supplementations

Data are expressed as the percentage of dry matter

\begin{tabular}{lcccccccc}
\hline Month & HA & NDF & ADF & LIG & HEM & CEL & IVOMD & TDN \\
\hline \multirow{5}{*}{ January } & 1.5 & 68.38 & 38.78 & 4.94 & 29.60 & 32.77 & 65.85 & 60.86 \\
& 2.0 & 71.55 & 41.08 & 5.48 & 30.46 & 34.00 & 68.25 & 63.61 \\
& 2.5 & 63.37 & 34.63 & 4.44 & 28.75 & 29.36 & 67.97 & 62.04 \\
February & 1.5 & 67.58 & 43.40 & 5.02 & 24.18 & 37.13 & 68.40 & 64.55 \\
& 2.0 & 67.18 & 41.55 & 4.68 & 25.64 & 36.35 & 70.64 & 65.02 \\
& 2.5 & 71.79 & 33.60 & 2.85 & 38.19 & 30.05 & 73.69 & 68.92 \\
March & 1.5 & 66.04 & 34.58 & 4.02 & 31.46 & 30.00 & 64.68 & 62.70 \\
& 2.0 & 66.99 & 37.19 & 4.28 & 29.81 & 32.75 & 65.06 & 63.70 \\
& 2.5 & 66.46 & 34.16 & 4.00 & 32.30 & 29.83 & 65.74 & 63.13 \\
& & & & & & & & \\
Jineral-protein-energy & & & \\
January & 1.5 & 68.18 & 36.40 & 4.70 & 31.78 & 30.78 & 66.93 & 60.42 \\
& 2.0 & 67.80 & 31.84 & 4.84 & 35.97 & 26.51 & 70.07 & 68.19 \\
& 2.5 & 67.98 & 35.22 & 4.80 & 32.76 & 29.57 & 66.61 & 62.41 \\
February & 1.5 & 67.64 & 37.56 & 4.50 & 30.09 & 32.14 & 71.21 & 64.84 \\
& 2.0 & 66.06 & 40.44 & 4.37 & 25.62 & 35.29 & 70.43 & 68.84 \\
& 2.5 & 67.48 & 42.97 & 5.16 & 24.51 & 37.61 & 65.89 & 62.55 \\
March & 1.5 & 67.07 & 40.31 & 5.68 & 26.76 & 33.68 & 70.87 & 60.81 \\
& 2.0 & 63.36 & 38.61 & 5.99 & 24.75 & 31.35 & 72.23 & 63.71 \\
& 2.5 & 63.85 & 41.23 & 4.85 & 22.62 & 36.14 & 64.49 & 59.92 \\
\hline
\end{tabular}

those observed in animals that were fed only the mineral mix. A significant difference was observed between the herbage allowance on the average daily weight gain, with the highest value achieved with $2.5 \mathrm{~kg} \mathrm{GDM} / \mathrm{kg} \mathrm{BW}$ (0.605 kg/animal.day).

\section{Discussion}

The herbage allowances that were lower than the pre-established values, in some periods, were a reflection of the climatic conditions, which varied over the course of the experiment (Table 1). Precipitation decreased sharply in March and especially April, reducing the development of the forage plants. Another contributing factor might have been that the stocking rate was controlled every 15 days. The herbage accumulation rate is determined by climatic conditions; thus, small variations immediately interfere with the growth of the forage plants, and these may not have been detected, hindering the control of the desired factors. Therefore, adjustments to stocking rates should be made in shorter time intervals.

These factors influence the search for more efficient parameters for grazing management. Measuring light interception can be used as a criterion of pasture management, but this is a complicated practice under field conditions and requires specific machinery (a photometer or sward analyser). However, the results for the forage sward height during the experimental period indicate that this is a parameter that could be adopted. According to Da Silva et al. (2013), evaluations of tropical pastures using grazing height can be employed consistently.
Table 7. Weight gain per hectare $(\mathrm{kg} / \mathrm{ha})$ and weight gain per animal (kg/animal.day) by heifers on Marandu pastures with different herbage allowances, in different periods, with different supplements

Means followed by the same lowercase letter to evaluate the effect of supplement and for period effect do not differ by Tukey's test at $10 \%$ probability. Mineral, mineral mix; multiple, multiple supplements (mineral, protein and energy)

\begin{tabular}{lccccc}
\hline Supplementation & $\begin{array}{c}\text { Herbage } \\
\text { allowance }\end{array}$ & January & $\begin{array}{c}\text { Month } \\
\text { February }\end{array}$ & March & Mean \\
\hline Mineral & 1.5 & 263.47 & 48.54 & 23.13 & $348.8 \mathrm{~b}$ \\
& 2.0 & 209.65 & 97.80 & 58.67 & \\
Multiple & 2.5 & 176.67 & 75.32 & 93.34 & \\
& 1.5 & 314.55 & 120.16 & 140.66 & $513.8 \mathrm{a}$ \\
& 2.0 & 257.15 & 155.13 & 96.67 & \\
Mean & 2.5 & 242.26 & 113.29 & 101.57 & \\
& - & $243.9 \mathrm{~A}$ & $101.7 \mathrm{~B}$ & $85.7 \mathrm{~B}$ & - \\
& & & Herbage & & \\
Average daily & & 1.5 & 2.0 & 2.5 & - \\
gain & & $0.461 \mathrm{~b}$ & $0.524 \mathrm{ab}$ & $0.605 \mathrm{a}$ & - \\
& & & & & \\
& Herbage & & Month & & Mean \\
Mineral & allowance & January & February & March & \\
& 1.5 & 0.672 & 0.160 & 0.083 & $0.423 \mathrm{~b}$ \\
& 2.0 & 0.693 & 0.300 & 0.234 & \\
Multiple & 2.5 & 0.822 & 0.367 & 0.474 & \\
& 1.5 & 0.920 & 0.418 & 0.513 & $0.637 \mathrm{a}$ \\
& 2.0 & 0.880 & 0.551 & 0.487 & \\
Mean & 2.5 & 1.020 & 0.462 & 0.480 & \\
\hline \multirow{3}{*}{2.5} & - & $0.835 \mathrm{~A}$ & $0.376 \mathrm{~B}$ & $0.378 \mathrm{~B}$ & - \\
\hline & & & & &
\end{tabular}

Overall, the responses of forage plants from temperate, tropical and subtropical climates can follow similar paths, which are conditioned and determined by variations in the structure of the forage sward. These variations are within considerable amplitudes of pasture conditions that can be maintained in practice according to variable management strategies with continuous or intermittent grazing, with no damage to the agronomic performance of the forage plants (persistence and production of herbage).

In a study on growing Nellore and Canchim breeds grazing on Marandu grass pastures, Da Silva et al. (2013) obtained optimal intake values, weight gain per animal and weight gain per hectare in a pasture maintained at 30 and $40 \mathrm{~cm}$. Additionally, according to those authors, in a continuous grazing system, Marandu grass pastures can be maintained at between 20 and $40 \mathrm{~cm}$ high, and the greatest weight gain per area unit occurs at $\sim 30 \mathrm{~cm}$ for growing animals, which is consistent with the values indicated for Xaraes grass (Brachiaria brizantha $\mathrm{cv}$. Xaraés).

No differences were observed in the herbage chemical composition, although it should be mentioned that the composition was evaluated based on an extrusa sample and that greater herbage allowances make it easier to select and ingest (leaf over stem and green material over dead material). Therefore, it can be affirmed that the differences in weight gain are a result of differences in the quantitative variables. NDF contents in the extrusa samples were between $63.36 \%$ and 
$71.79 \%$ during the experimental period and were lower than those reported by Zervoudakis et al. (2002) in samples of Marandu grass $(72.5 \%)$ in an intermittent grazing system during the rainy season (Table 5). ADF contents varied from $31.84 \%$ to $42.97 \%$, which is similar to the values reported by Canesin et al. (2007) in simulated-grazing samples of Marandu grass and in whole-plant samples $(40.3 \%)$.

Non-protein $\mathrm{N}$ levels obtained herein corresponded to $30.54 \%$ of the total $\mathrm{N}$, on average (Table 5), and may be attributed to the contribution of the non-protein $\mathrm{N}$ from the herbage itself, which is a typical situation in tropical grasses in periods directly following the occurrence of rainfall (Poppi and McLennan 1995).

In the present study, the digestibility values were satisfactory for the appropriate performance of grazing animals. Hernandez et al. (1995) observed similar values in extrusa samples of Marandu under an intermittent stocking rate $(66.2 \%)$. However, Bittencourt and Veiga (2001) observed a digestibility of $53.3 \%$ to $57.5 \%$ in leaves of Marandu grass under intermittent grazing. Euclides et al. (1993) found a digestibility of $58.7 \%$ in samples of leaves of the same cultivar during the rainy season.

According to the data available in the literature (Poppi and McLennan 1995; Moore et al. 1999), the supply of readily available energy can minimise the $\mathrm{N}$ losses of the herbage due to the greater synchronism between the availability of energy and ammonia in the rumen, which results in an increase in the microbial protein synthesis. Conversely, supplementation with low rumen degradation protein enables the absorption of amino acids in the intestine, resulting in a positive effect on herbage intake and animal performance (Siebert and Hunter 1982).

The supply of bypass protein via supplements for beef cattle on pastures may improve animal performance, even in situations where the herbage meets the $\mathrm{N}$ requirement for microbial protein synthesis. It can be inferred that the supplement offered to the animals consuming herbage with this concentration of fraction A should present low protein and high energy values or a greater proportion supply of rumen undegradable protein, leading to an increase in microbial synthesis (Poppi and McLennan 1995).

Supplementing the diet for grazing cattle may result in excess $\mathrm{N}$, and in such situations, performance has a greater correlation with energy uptake (Detmann et al. 2014). It should be stressed that during the entire experimental period, the observed CP values were above the critical limit for the proper function of the rumen in all treatments, which in tropical grasses diets is between $6.0 \%$ and $7.0 \% \mathrm{CP}$ (Minson 1990).

According to Poppi and McLennan (1995), CP/DOM (digestible organic matter) ratios above 210 result in $\mathrm{N}$ losses by the animal. In contrast, $160 \mathrm{~g} \mathrm{CP} / \mathrm{kg} \mathrm{DOM}$ provides optimal conditions for the synthesis of microbial protein, and $130 \mathrm{~g} \mathrm{CP} / \mathrm{kg}$ DOM results in a deficiency. In the present study, the ratios between $\mathrm{CP}$ and DOM in the herbage were 168, 128 and $137 \mathrm{~g} \mathrm{CP} / \mathrm{kg}$ DOM for February, March and April, respectively. Based on the calculated values, it can be inferred that the ratios were not appropriate to maximise the synthesis of microbial protein in March and April.
The improvement in performance as herbage allowance increases may continue until it is stable for more generous herbage allowances. However, the gain per area tends to decrease with medium-to-high herbage allowances. In February, when there was greater availability of green forage, the animals presented a greater weight gain, both per area and per animal. From March, when there was a reduction in green material availability, the animals showed a decrease in weight gain. It is noteworthy that even in March and April the observed weight gains were satisfactory for the studied systems. Another factor that should be taken into account is that even at the lowest availability (1.5 kg GDM/kg BW) animals are able to select and ingest the green leaves.

Supplementation during the rainy season at moderate levels, as utilised in this study $(0.3 \% \mathrm{BW})$, can promote changes in the displacement of curves of individual weight gain and gain per area above those observed in the unsupplemented animals. This finding cannot be attributed to the substitutive-associative effect, which would affect the weight gain of the animals and the stocking rate according to the substitution of the intake of herbage as a concentrate, but rather to an increase in weight gain that is consequently reflected in the gain per area. There is a consensus in the literature that supplementation up to this level is not substitutive but is associative or has combination effects. Therefore, it can be inferred that strategic supplementation can elevate the animal weight gain and gain per area simultaneously.

\section{Conclusions}

Supplying an additional energy and protein source in the diet of beef heifers during the rainy season and the rainy-dry season transition, at the rate of $0.3 \%$ of $\mathrm{BW}$, provides a greater weight gain and greater production per hectare, simultaneously, compared with animals receiving only a mineral mix, regardless of the herbage allowance.

\section{References}

Association of Official Analytical Chemists - AOAC (1990) 'Official methods of analysis of the Association of Analytical Chemists.' 14th edn. (AOAC: Washington, DC)

Barbosa RA, Nascimento D Jr, Euclides VPB, Da Silva SC, Zimmer AH, Torres RAA, Jr. (2007) Capim-tanzânia submetido a combinações entre intensidade e frequência de pastejo. Pesquisa Agropecuaria Brasileira 42, 329-340. doi:10.1590/S0100-204X2007000300005

Bittencourt PCS, Veiga JB (2001) Avaliação de pastagens de Brachiaria brizantha cv. Marandu em propriedades leiteiras de Ururá, região da Transamazônica, Pará, Brasil. Pastures Tropicales 23(2), 2-9.

Canesin RC, Berchielli TT, Andrade P, Reis RA (2007) Desempenho de bovinos de corte mantidos em pastagem de capim marandu submetidos a diferentes estratégias de suplementação no período das águas e da seca. Revista Brasileira de Zootecnia 36(2), 411-420. doi:10.1590/S1516-35 982007000200019

Casagrande DR, Azenha MV, Valente ALS, Vieira BR, Moretti MH, Ruggieri AC, Berchielli TT, Reis RA (2011) Canopy characteristics and behavior of Nellore heifers in Brachiaria brizantha pastures under different grazing heights at a continuous stocking rate. Revista Brasileira de Zootecnia 40(11), 2294-2301. doi:10.1590/S1516-359820 11001100003

Da Silva SC, Gimenes FMA, Sarmento DOL, Sbrissia AF, Oliveira DE, Hernadez-Garay A, Pires AV (2013) Grazing behaviour, herbage intake 
and animal performance of beef cattle heifers on marandu palisade grass subjected to intensities of continuous stocking management. The Journal of Agricultural Science 151, 727-739. doi:10.1017/S00 21859612000858

Detmann E, Valente EEL, Batista ED, Huhtanen P (2014) An evaluation of the performance and efficiency of nitrogen utilization in cattle fed tropical grass pastures with supplementation. Livestock Science $\mathbf{1 6 2}$ 141-153. doi:10.1016/j.livsci.2014.01.029

Euclides VPB, Zimmer AH, Macedo MCM, de Oliveira MP (1993) Evaluation of Brachiaria decumbens and Brachiaria brizantha under grazing. In '17th international grassland congress'. Rockhampton, Australia. pp. 1997-1998. (New Zealand Grassland Association: Palmerston North)

Gontijo Neto MM, Euclides VP, Nascimento Júnior D (2006) Consumo e tempo diário de pastejo por novilhos nelore em pastagem de capimtanzânia sob diferentes ofertas de forragem. Revista Brasileira de Zootecnia 35(1), 60-66. doi:10.1590/S1516-35982006000100007

Hernandez M, Argel PJ, Ibrahim MA, Mannetje T (1995) Pasture production, diet selection an liveweight gains of cattle grazing Brachiaria brizantha with or without Arachis pintoi at two stockings rates in the Atlantic Zone of Costa Rica. Tropical Grasslands 29, 134-141.

Licitra G, Hernandez TM, Van Soest PJ (1996) Standardization of procedures for nitrogen fractionation of ruminant feeds. Animal Feed Science and Technology 57, 347-358. doi:10.1016/0377-8401(95)00 837-3

Mauricio RM, Mould FL, Dhanoa MS, Owen E, Channa KS, Theodorou MKA (1999) Semi-automated in vitro gas production technique for ruminant feedstuff evaluation. Animal Feed Science and Technology 79(4), 321-330. doi:10.1016/S0377-8401(99)00033-4

Menke KH, Steingass H (1988) Estimation of the energetic feed value obtained from chemical analysis and in vitro gas production using rumen fluid. Animal Research and Development 28, 7-55.

Mertens DR (2002) Gravimetric determination of amylase-treated neutral detergent fibre in feeds with refluxing beakers or crucibles: a collaborative study. Journal of AOAC International 85, 1217-1240.

Minson DJ (1990) 'Forage in ruminant nutrition.' (Academic Press: New York, NY)

Moore JE, Brant MH, Kunkle WE, Hopkins DI (1999) Effects of supplementation on voluntary forage intake, diet digestibility, and animal performance. Journal of Animal Science 77, 122-135.
Mota M, Rodríguez R, Solanas E (2005) Evaluation of four tropical browse legumes as nitrogen sources: comparison of in vitro gas production with other methods to determine N degradability. Animal Feed Science and Technology 123-124, 341-350. doi:10.1016/j. anifeed sci.2005.04.018

National Research Council (NRC) (2001) 'Nutrient requirements of dairy cattle.' 7th edn. (National Academic Press: Washington, DC)

Poppi DP, McLennan SR (1995) Protein and energy utilization by ruminants at pasture. Journal of Animal Science 73, 278-290.

Reis RA, Valente ALS, Santos SMC, Souza FHM, Berchielli TT, Ruggieri AC, Santana SS, Serra JM (2013) Performance of young Nelore bulls grazing Marandu grass pasture at different heights. Tropical Grasslands 1, 114-115.

SAS Institute (2002) 'SAS/STAT user's guide.' (SAS Institute: Cary, NC) Siebert BD, Hunter RA (1982) Supplementary feeding of grazing animals. In 'Nutritional limits to animal production from pasture'. (Ed. JB Hacker) pp. 409-425. (Commonwealth Agricultural Bureau: Farnham Royal)

Sniffen CJ, O'Connor JD, Van Soest PJ, Fox DG, Russell JB (1992) A net carbohydrate and protein system for evaluating cattle diets: II. Carbohydrate and protein availability. Journal of Animal Science 70, 3562-3577.

Sollenberger LE, Cherney DJR (1995) Evaluating forage production and quality. In 'Forages, Vol. 2: the science of grassland agriculture'. (Eds RF Barnes, DA Miller, CJ Nelson) pp. 97-110. (Iowa State University Press: Ames, IA)

Theodorou MK, Williams BA, Dhanoa MS, Mcallan AB, France J (1994) A simple gas production method using a pressure transducer to determine the fermentation kinetics of ruminant feeds. Animal Feed Science and Technology 48, 185-197. doi:10.1016/0377-8401(94)90 171-6

Van Soest PJ, Robertson JB (1985) 'Analysis of forages and fibrous foods.' (Cornell University Press: Ithaca, NY)

Zervoudakis JT, Paulino MP, Detmann E, Valadares Filho SC (2002) Desempenho de novilhas mestiças e parâmetros ruminais em novilhos suplementados durante o período das águas. Revista Brasileira de Zootecnia 31(2), 1050-1058. doi:10.1590/S1516-35982002000400030 